\title{
Distribution Problems in Private Bank Led life Insurance Firms: A Contrasting Scenario in the Indian Context
}

\author{
Tanmay Pant, Sandeep Arya
}

\begin{abstract}
Life insurance distribution in India is at an inflection point. Whilst life insurance as a phenomenon continues to be an enigma at best, it is its distribution aspect which seems to have taken the cake. Companies are grappling with the problem of designing an appropriate distribution channel mix. At a time when an industry-wise (private companies sans LIC) marked shift could be seen in favour of bancassurance over agency as a channel of choice, it is interesting that upon deeper analysis an intriguing phenomenon over the last five years has occurred, wherein two leading private bank led life insurance firms, namely HDFC Life and ICICI Prudential - both having the support of big banks (HDFC bank \& ICICI bank); one being a non bank-promoted entity (HDFC Life), the other a bank-promoted one (ICICI Prudential) - are selling more through bancassurance - in line with the industry trends - but are either dismal in agency numbers or are at least preserving them or at times, are ahead of the industry agency numbers, even when the common refrain is to go the bancassurance way. In fact, ICICI Prudential is overshooting the industry bancassurance trend and HDFC more or less equals it. The last five years have unfolded marked variations in distribution for both these companies, manifestations of which are different. Equally confounding is the fact that with the direct channel (read online) - showing tremendous potential and growth - poised to make further disruptions, the resultant is an uncertain distribution landscape with no clear pattern in sight. Should these companies dispense with the agency channel? Or should they preserve agency? Or should they look to the direct / online channel. How do they strike a balance when disruptions are bound to happen further? This paper attempts to delineate the distribution patterns of these similar bank led companies and the implications thereof of such patterns.
\end{abstract}

Keywords : agency, bancassurance, bank-promoted, non bank-promoted.

\section{INTRODUCTION}

$T_{\text {he life insurance penetration and density numbers for }}$ India cut a sorry figure. From the time of privatisation - year 2000 onwards - till now when it could have turned out to be an epic success story, the said numbers flatter to decieve in a big way. A look at these numbers (Exhibhit $1 \& 2$ ) reflect a harsh reality that India, inspite of a flourshing middle class and a market ripe for the taking has failed to translate potential into performance.

Revised Manuscript Received on July 22, 2019.

Tanmay Pant, Research Scholar, Dept. of HSS, JUET, Guna (M.P.) \& Assistant Professor, GIBS, Rohini, Delhi, India

Dr. Sandeep Arya, Assistant Professor, Dept. of HSS, JUET, Guna (M.P.), India
Exhibit 1: Life Insurance Penetration

\begin{tabular}{|l|l|l|l|l|l|}
\hline Countries & $\mathbf{2 0 1 3}$ & $\mathbf{2 0 1 4}$ & $\mathbf{2 0 1 5}$ & $\mathbf{2 0 1 6}$ & $\mathbf{2 0 1 7}$ \\
\hline & \multicolumn{5}{|c|}{ Life Insurance Penetration } \\
\hline Australia & 3.00 & 3.80 & 3.50 & 2.99 & 2.33 \\
\hline Brazil & 2.20 & 2.10 & 2.10 & 2.28 & 2.28 \\
\hline France & 5.70 & 5.90 & 6.20 & 6.06 & 5.77 \\
\hline Germany & 3.10 & 3.10 & 2.90 & 2.75 & 2.63 \\
\hline Russia & 0.10 & 0.20 & 0.20 & 0.25 & 0.36 \\
\hline South Africa & 12.70 & 11.40 & 12.00 & 11.52 & 11.02 \\
\hline Switzerland & 5.30 & 5.10 & 5.10 & 4.72 & 4.41 \\
\hline United Kingdom & 8.80 & 8.00 & 7.50 & 7.58 & 7.22 \\
\hline United States & 3.20 & 3.00 & 3.10 & 3.02 & 2.82 \\
\hline & & & & & \\
\hline Asian Countries & & & & & \\
\hline Hong Kong & 11.70 & 12.70 & 13.30 & 16.20 & 14.58 \\
\hline India\# & $\mathbf{3 . 1 0}$ & $\mathbf{2 . 6 0}$ & $\mathbf{2 . 7 0}$ & $\mathbf{2 . 7 2}$ & $\mathbf{2 . 7 6}$ \\
\hline Japan\# & 8.80 & 8.40 & 8.30 & 7.15 & 6.26 \\
\hline Malaysia\# & 3.20 & 3.10 & 3.40 & 3.15 & 3.32 \\
\hline Pakistan & 0.50 & & & & \\
\hline PR China & 1.60 & 1.70 & 2.00 & 2.34 & 2.68 \\
\hline Singapore & 4.40 & 5.00 & 5.60 & 5.48 & 6.64 \\
\hline South Korea\# & 7.50 & 7.20 & 7.30 & 7.37 & 6.56 \\
\hline Sri Lanka & 0.50 & 0.50 & 0.50 & 0.52 & 0.54 \\
\hline Taiwan & 14.50 & 15.60 & 15.70 & 16.65 & 17.89 \\
\hline Thailand & 3.80 & 3.60 & 3.70 & 3.72 & 3.59 \\
\hline World & $\mathbf{3 . 5 0}$ & $\mathbf{3 . 4 0}$ & $\mathbf{3 . 5 0}$ & $\mathbf{3 . 4 7}$ & $\mathbf{3 . 3 3}$ \\
\hline & & & & & \\
\hline
\end{tabular}

Source: Swiss Re, Sigma various volumes; data relates to Calendar year;

* Insurance penetration is measured as ratio of premium to GDP;

\# data relates to financial year. 
Exhibit 2: Life Insurance Density

\begin{tabular}{|l|l|l|l|l|l|}
\hline \multirow{2}{*}{ Countries } & $\mathbf{2 0 1 3}$ & $\mathbf{2 0 1 4}$ & $\mathbf{2 0 1 5}$ & $\mathbf{2 0 1 6}$ & $\mathbf{2 0 1 7}$ \\
\cline { 2 - 6 } & \multicolumn{4}{|l}{ Life Insurance Density } \\
\hline & 2056. & 2382. & 1830. & \multicolumn{1}{l|}{1558.} & 1304. \\
Australia & 0 & 0 & 0 & 5 & 0 \\
\hline Brazil & 246.0 & 222.0 & 178.0 & 195.5 & 224.0 \\
\hline & 2391. & 2552. & 2263. & 2227. & 2222. \\
France & 0 & 0 & 0 & 7 & 0 \\
\hline & 1392. & 1437. & 1181. & 1150. & 1169. \\
Germany & 0 & 0 & 0 & 6 & 0 \\
\hline Russia & 19.0 & 20.0 & 15.0 & 22.4 & 39.0 \\
\hline South & & & & & \\
Africa & 844.0 & 748.0 & 688.0 & 615.8 & 674.0 \\
\hline & 4211. & 4391. & 4079. & 3700. & 3522. \\
Switzerland & 0 & 0 & 0 & 3 & 0 \\
\hline United & 3474. & 3638. & 3292. & 3033. & 2873. \\
Kingdom & 0 & 0 & 0 & 2 & 0 \\
\hline United & 1684. & 1657. & 1719. & 1724. & 1674. \\
States & 0 & 0 & 0 & 9 & 0 \\
\hline & & & & & \\
\hline Asian & & & & & \\
Countries & & & & & \\
\hline & 4445. & 5071. & 5655. & 7065. & 6756. \\
Hong Kong & 0 & 0 & 0 & 6 & 0 \\
\hline India\# & $\mathbf{4 1 . 0}$ & $\mathbf{4 4 . 0}$ & $\mathbf{4 3 . 0}$ & $\mathbf{4 6 . 5}$ & $\mathbf{5 5 . 0}$ \\
\hline & 3346. & 2926. & 2717. & 2803. & 2411. \\
Japan\# & 0 & 0 & 0 & 4 & 0 \\
\hline Malaysia\# & 341.0 & 338.0 & 316.0 & 298.3 & 339.0 \\
\hline Pakistan & 6.0 & 7.0 & 8.0 & 9.2 & 9.0 \\
\hline PR China & 110.0 & 127.0 & 153.0 & 189.9 & 225.0 \\
\hline & 2388. & 2840. & 2932. & 2894. & 3835. \\
Singapore & 0 & 0 & 0 & 5 & 0 \\
\hline South & 1816. & 2014. & 1940. & 2049. & 1999. \\
Korea\# & 0 & 0 & 0 & 6 & 0 \\
\hline Sri Lanka & 16.0 & 17.0 & 19.0 & 21.2 & 22.0 \\
\hline & 3204. & 3371. & 3397. & 3598. & 4195. \\
Taiwan & 0 & 0 & 0 & 7 & 0 \\
\hline Thailand & 214.0 & 198.0 & 215.0 & 222.0 & 237.0 \\
\hline World & $\mathbf{3 6 6 . 0}$ & $\mathbf{3 6 8 . 0}$ & $\mathbf{3 4 6 . 0}$ & $\mathbf{3 5 3 . 0}$ & $\mathbf{3 5 3}$ \\
\hline & & & & & \\
\hline
\end{tabular}

Source: Swiss Re, Sigma various volumes;

Data relates to Calendar year.

* Insurance density is measured as ratio of premium (in US Dollar) to total population.

\# data relates to financial year.

The life insurance penetration and density numbers in India are way below the mark and compares unfavorably with the average figures worldwide (Exhibit 1\&2). Even in Asia, the numbers don't inspire confidence (Exhibit 1\&2). A host of factors could be attributed towards such a dismal show: awareness, products, distribution etc. There is no denying the fact that government support post reforms in 1999 has increased. The companies, too have gone all ballistic in their efforts to reach to the customers with novel yet suitable products. Then why is that with more or less the same products, some companies are doing well while most are not? What they have not done well and which the authors suspect to be the missing link, is the distribution aspect. It is an aspect of life insurance, which, is slowly but surely defining the companies (Mehta, 2015). India is By distribution the authors do not only mean the lack of reach of the companies but also not being able to zero-in on the ultimate optimum distribution mix. That is easier said than done and hence when technology has spread its wings, this case study could not have come at a more crucial juncture as the technology is playing a dual role - one of an up and coming distribution channel (read online) and the other of a facilitator (to supporting traditional / other channels).

\section{Why the significance of distribution?}

In India, the core of distribution today comprises majorly of the agents, banks, brokers, corporate agents other than banks, malls, the internet etc. Technology is all pervasive in most of these existing channels and has been largely responsible for the proliferation of newer innovative channels. The combined effect is a big market like India being served through multiple touch-points by a relatively large number of intermediaries, some as different as chalk and cheese. It makes it even more puzzling that in spite of such pivotal bases covered - as far as the distribution per se is concerned - the life insurance penetration and density numbers have been far from spectacular; in fact it has been awful (Exhibit 1\&2). If this is intriguing, the intrigue, though just starts with the above fact. Add to the above, the company origin and ownership structures also have a tremendous bearing on distribution as well.

Distribution in India is a microcosm of the larger phenomenon of life insurance but in the last decade or so it seems to have taken the pie as far as the intrigue factor is concerned. With companies varying in terms of origin and ownership, it makes a lot of sense therefore to gauge the reasons for the underperformance of distribution with regards to penetration and density. Adding to the intrigue of distribution is a recent study (Cognizant report, 2014), which while acknowledging that companies have moved to a multi-distribution regime, strongly warns them against further disruptions in the future. The said study warns the companies to throw caution to the wind towards further disruptions in distribution as none of them have mastered the art of finding the optimum distribution mix. It argues that the companies remaining ahead of the curve (future of distribution, FOD) will be the ones standing out in the crowd. A unified view of the three - the company, the channel and the customer would address the distribution woes and contribute to decent penetration and density numbers. Thus far, we have been able to showcase the distribution conundrum. So whilst distribution continues to be a big phenomenon in life insurance, it is an even more intriguing and never before highlighted phenomenon within private bank-originated / promoted / group companies. In our endeavor to bring to the fore these intricacies, the current case study attempts to compare the distribution trends of two similar companies: both private, one bank-promoted (ICICI Prudential) and the other - HDFC Life, a non bank-promoted but having a large bank (HDFC Bank) as its group company.

Two channels, namely the Agency and Bancassurance account for around $85 \%$ of the new premium coming in. The rest 
of the premium is accounted for by the direct business (including the internet), brokers and others. While the online channel has seen phenomenal growth, it, at best, still remains a channel of hope. A pertinent question arises as to which channel of distribution accounts for the growth of the firm or how does a balancing of distribution mix be carried out by companies because while each channel has its own merits and demerits, finding an optimum mix is often a challenge. Towards that end, the two firms in this case study, present a unique case of finding an answer to the above. Both firms are leading firms in the private space and have large banks either as promoters or group companies.

\section{LITERATURE REVIEW}

Since a myriad of channels operate currently co-exist, the larger share of the pie is shared between the agents, bancassurance and direct channels (mainly online), with brokers showing their presence but not enough of it so as to gain some reckoning. So the literature review will mainly cater to the channels doing bulk of business, with an additional mention of the multi-distribution mechanism.

Worldwide, and in India, agents have held sway for long as the channel of choice until a marked shift in favor of bancassurance happened some years back especially for private players. Historically India has had LIC as the only insurer for long and agents ruled the roost. Privatization gave novel channels like bancassurance which changed the status quo and paved way for other innovative channels. Back in the day, the reasons for a flourishing agency channel was that insurers were of the view that sales could be maximized by having a large sales force (Finsinger and Schmidt, 1993). Bancassurance has come up the rungs as a channel of choice and a serious contender to agency. Recent changes have led to the alteration of the financial service industry in the west (Baumol, Panzar \& Willig, 1982; Benoist, 2002; Bergendahl, 1995) and India caught up with them post privatization in insurance. This led to the integration of banks and insurance leading to the emergence of the bancassurance channel. Over the years the integration of banks with the insurance companies have led to the reorganization of the financial services industry in the USA, Europe and Latin America. A case in point is the breaking of the traditional barriers between banking and insurance through integrated institutions offering a range of services in the UK (Morgan, 1994; Salomon, 1990). The USA also saw a watershed moment when the deregulation under the Gramm-Leach-Bliley Act (GLBA) of 1999 legalized bancassurance and eventually led to its spread, geographically. The new legislation has a scope for formation of financial holding companies offering banking, insurance and other financial activities.(Field et al., 2007).

Close home to India, in the Asian context, Bancassurance in Taiwan grew mainly because of 'over-banking'. Taiwan Government owned most of the banks before 1991 (Chen and Yeh, 1998), an establishment which didn't last after the Commercial Bank Establishment Promotion Decree in 1991. Subsequently, the banking environment changed drastically with private local and foreign banks entering the market. This led to the 'over-banking' problem where there were far too many banks resulting in extra capacity and inefficiency. It paved the way for non-traditional businesses for the banks and bancassurance was one of them. It -bancassurance - also proved to be the fastest entry route for new insurers to build cost-effective marketing channels.

Bancassurance has grown much in India, to the extent that it is the channel of choice for private players (HDFC Annual Report, 2019). A recent study (Satsangi, 2014) on the effectiveness of bancassurance in India reveal that the channel has grown enormously during the last ten years mainly for the private players but failed to make a mark in LIC's distribution set up. Direct channel (mainly online) has, of late, been one of the most sought-after channels for simple life insurance products. In simplest terms, Direct marketing is flow of goods and services form producers to customers without intermediaries (Kotler and Keller, 2006; Bearden et al., 2004). The advantage lies in the fact that marketers obtain a more direct response from customers and, in return, the customers have access to more products than retail. Additionally, customers have the luxury of shopping through the confines of their homes or offices (Wilkinson et al., 2007). Scovotti and Spiller (2006), in light of the aforesaid, opine that direct marketing has assumed significance to the extent that it is a fundamental tool in a growing variety of business, most notably that of financial services (Bearden et al., 2004). Thomas (2007), views direct marketing as always more efficient than mass marketing. With technology playing a pivotal role in redefining all channels, a multi-channel distribution aimed at the customer segments is being looked at by most companies.

The fragmentation of markets, globally, has further strengthened the need of having a strategy of multiple channels to cater to potential buyers at multiple touch-points; the rationale being to allow customers to buy the way they want to and where they want to (Bearden et al., 2004). The multiple channel strategy comes with a host of advantages, the biggest being the extended coverage of the market through different channels (Coelho and Easingwood, 2004). Additionally, customer knowledge and information can be shared by different channels, helping them to strategize (Easingwood and Coelho, 2003). Multiple distribution channels, apart from the outreach, help in meeting the needs of existing customers in a better way (Tsay and Agrawal, 2004). Customer preferences and characteristics of the product, in the current scheme of things decide the purchase of insurance products of an insurance firm via different channels. It goes without saying, then that firms with broad product lines will benefit most from the distribution through multiple channels (Webb, 2002). Contrary to most of the literature, as per a recent study (Cognizant: Future of Distribution, 2014), it is the channels (a tell-tale sign) which will continue to influence the type of insurance products. The down side of using multiple channels is that cost disadvantages - arising due to high investment costs necessary to establish an additional distribution channel - and high coordination costs 
- arising between the channels - can disrupt a company (Easingwood and Storey, 1996). Channel cannibalization - a practice where customers make only use of new distribution channels (e.g.. direct / online ) to inform themselves but buy on established channels (e.g. tied agents) - too, leads to redirection of turnover and profits from one channel to the other (Dzienziol et. al, 2002).

The moot question, though, remains: how to strike a balance between the channels so as to arrive at an optimum distribution mix? And, in addition, which channels to be given more weight age in terms of efficiency? While there are studies, mainly in the Taiwanese context, which have found the efficiency of channels for different life insurance companies, it cannot be the template for India or elsewhere which operate on different regulatory mechanisms and company origin and ownership structures. Nevertheless, the Taiwanese studies (Chen \& Chang, 2010) found that a direct distribution strategy is more efficient than a non- direct distribution strategy. Chang, Peng \& Fan (2011), in yet another Taiwanese study found that the efficiency of a traditional sales channel was significantly higher than a comparable bancassurance channel. In recent times, one of the most central points of majorly all academic works is to find the most profitable distribution channel for insurers. A plethora of works have emanated in the United States where due to the differences across life insurance distribution systems being less profound than those in property-liability insurance, most works of distribution channels have focused on property-liability insurers rather than life insurers. A case in point is Joskow's (1973) pioneer research of cost and profit comparison. His conclusion in the detailed study of the property and liability insurance industry in the United States was that the combined influence of state regulation, cartel pricing and other legal considerations caused several problems in the property and liability insurance industry. $\mathrm{He}$ estimated that the expense ratios of insurers using direct writers were approximately 11 per cent lower than those of insurers using independent agencies.

Recent studies examine cost differences for later periods and have refined Joskow's basic analysis. Still many others ( Cummins \& Van Derhei, 1979; Baresse \& Nelson, 1992) find results that are consistent with Joskow's. Regan (1999) extends this analysis to a much larger sample of firms and concludes that direct writers' cost advantages differ significantly across lines. Rather than testing for differences in expense ratio, Berger, Cummins and Weiss (1997) use a frontier efficiency analysis to examine differences in both cost and profit effi ciency across property-liability insurance distribution systems. The said authors, in sync with earlier studies, found that insurers using independent agencies are significantly less cost effi cient than those using direct writers. Regan and Tzeng (1999) fi nd a strong correlation between ownership form and distribution system in the aggregate data. Klein, Crawford \& Alchian (1978) and Williamson (1981) found that direct channels were more effective when the products required specialized knowledge or when difficult tasks were involved in the sales relationship, because firms could better monitor and motivate their difficult-to-replace distribution agents. Baranoff et. al (2000) also finds that broker-oriented insurer will increase agency expenses and reduced return of capital because of the necessity of maintaining two distribution systems, in comparison with agency-oriented companies, which operate with a single system.

Worldwide, the exclusive agent channel was the major channel of life insurers in the early days, but the utilization of multiple-distribution channels (for example, Agency, Brokerage, Direct Marketing, and Bancassurance and so on) has become increasingly prevalent in recent years. In order to adapt to environmental changes, life insurers continue to develop their direct marketing, brokerage and agency distribution channels in order to secure market shares, to better control the operations of intermediaries' selling, and to use excess funds generated in the business (Marcel \& Doyle, 1979). Jury is still out on whether multiple channels enable firms to capture customers in different market segments as they pose many challenges, including channel conflict (Webb, 2002) and pricing policy, for different distribution channels strategies (Tang \& Xing, 2001).

Specifically in the Indian context, to the best of knowledge of the authors, not a single study, Sinha (2013) apart, has analysed the distribution trends of companies. Even Sinha's (2013) study does not compare private bank led companies with regards to distribution. So even though some work has been done, notably so of Sinha (2013) and Lakshmikutty \& Sridaran (2005), regarding the distribution phenomenon and trends, none of two have compared distribution of similar private bank led companies and the implications, thereof, for the practitioners and academicians. Sinha (2013) has explored 7 leading private players with regards to their distribution mix over a 5 year period ( 2005-06 to 2009-10). Acknowledging the fact that with an evolving distribution set up, multiple distribution channels would be required to get to the customer into action, he stresses the need for a multi-distribution regime. Sharma \& Saxena (2009) have emphasized upon the absence of rural oriented channels while discussing about the changes in the distribution mechanism and highlighted the importance of multi-distribution channels in the insurance industry. Lakshmikutty and Bhaskar (2005) have mentioned the current state of affairs of most distribution channels and also stressed on the emergence of some new channels coming up. Tone \& Sahoo (2005) studied the cost efficiency of the Life Insurance Corporation of India. Thus, we, the authors, by virtue of this study attempt to add to the extant literature, the contrasts in distribution mechanism - and their implications thereof - of two private bank led life insurance firms in India.

The industry (private players) distribution trend:

First have a look at the business numbers (premium) achieved through the agency and banca and the online channel over the last five years and interpret the same:

The industry trend (for private players) over the last five years (Exhibit 3) has seen the agency numbers shrinking by a good $10 \%$ and sliding all through. The final figure (2018-19) is

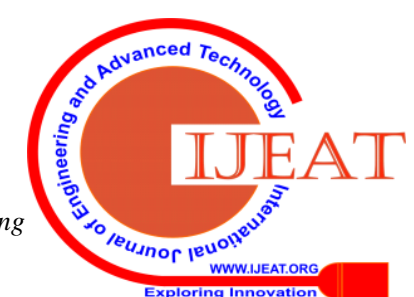


$26 \%$. The corresponding figures for banca shows an improvement of $7 \%$ with the last three fiscals steady at $52 \%$ and the final figure (2018-19) at 54\%. The online channel has been steadily rising and capped off at 14\% (2018-19), a jump of $5 \%$ from the $9 \%$ of $2014-15$. A point of note is that when we add LIC to the above mix, the numbers are skewed in favour of the agency (LIC being an agent centric company).
Since the case is about two leading, almost similar, bank-promoted / bank-originated companies (HDFC Life \& ICICI Prudential), a private sector industry data makes sense.

\section{Exhibit 3: Private players distribution trend}

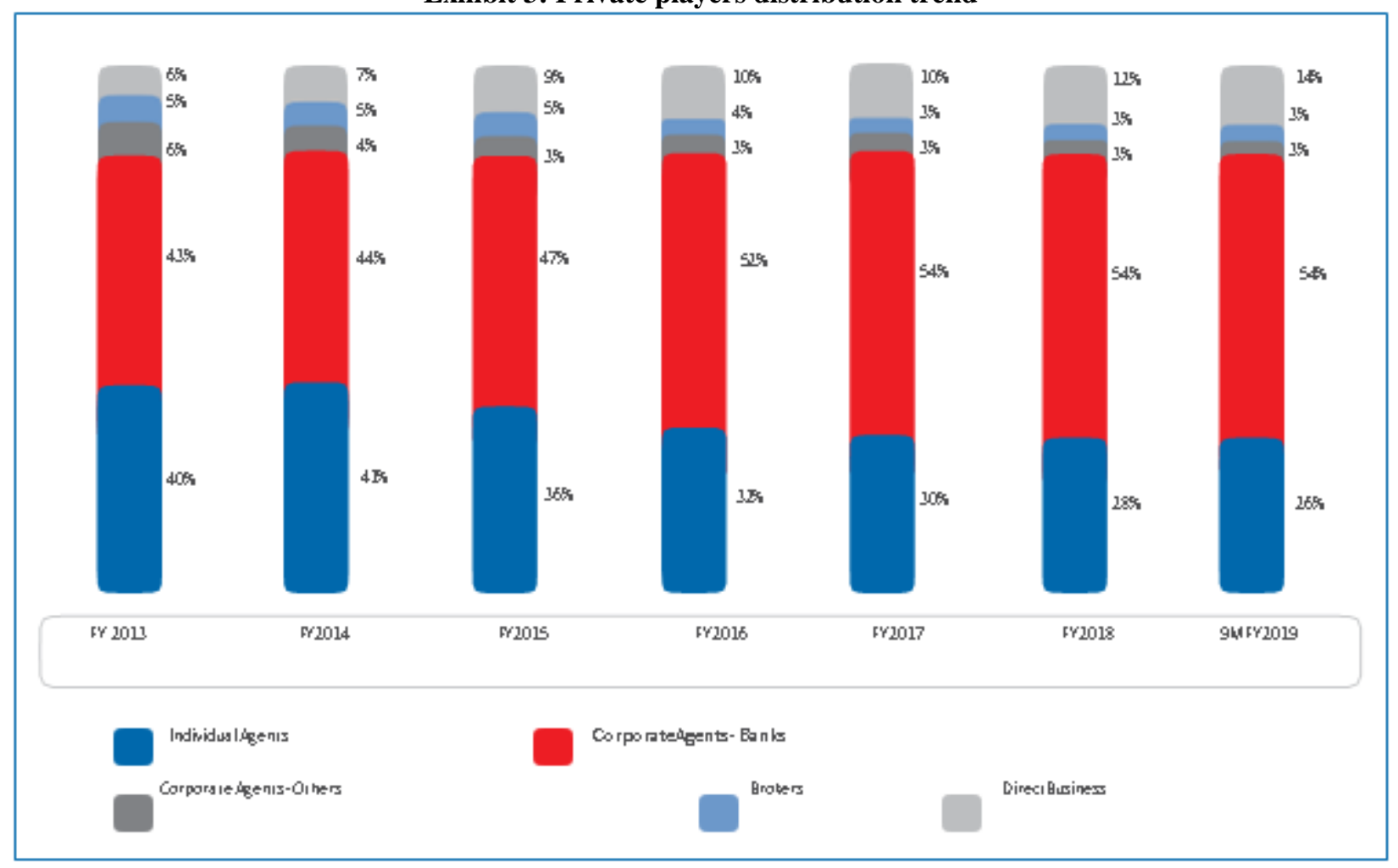

(Source: HDFC Life Insurance Annual Report, 2019)

A look at the agency, banca and direct / online channel trends industry trend should give vital insights into the intricacies of (business numbers in terms of premium) in case of HDFC Life the distribution mix of the aforesaid firms, each dynamic in and ICICI Prudential (Exhibit 4, 5, $6 \& 7$ ) over a period of time their own right.

(last 5 years) and the comparison with the corresponding

Exhibit 4: HDFC Life channel business numbers (premium):

\begin{tabular}{|l|l|l|l|}
\hline $\begin{array}{c}\text { HDFC } \\
\text { LIFE }\end{array}$ & AGENT & BANK & $\begin{array}{l}\text { DIRECT } \\
\text { ONLINE }\end{array}$ \\
\hline $2014-15$ & $16.50 \%$ & $67 \%$ & $10 \%$ \\
\hline $2015-16$ & $13.40 \%$ & $68 \%$ & $12 \%$ \\
\hline $2016-17$ & $15.40 \%$ & $61 \%$ & $15 \%$ \\
\hline $2017-18$ & $13.00 \%$ & $58 \%$ & $19 \%$ \\
\hline $2018-19$ & $13.70 \%$ & $49 \%$ & $31 \%$ \\
\hline
\end{tabular}

(Source: Author compilation through HDFC Life Annual Reports) 
Exhibit 5: HDFC Life channel business numbers (premium):

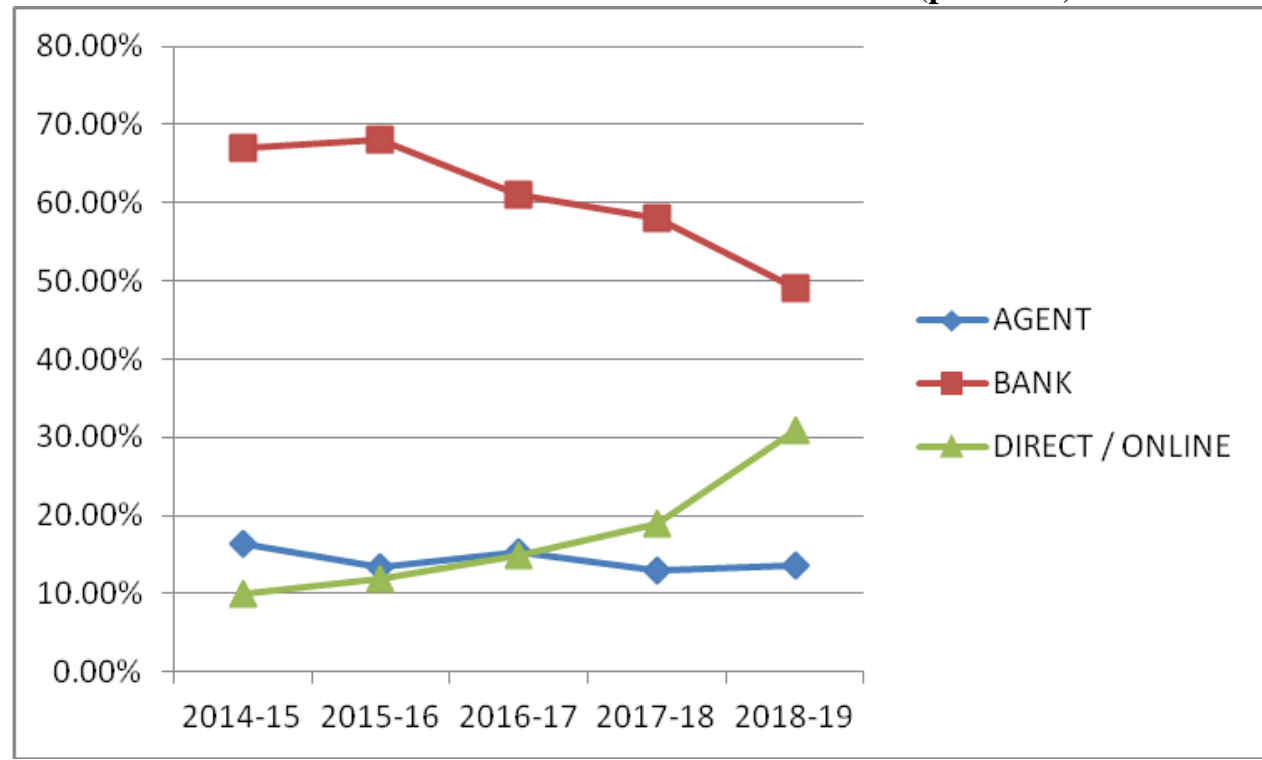

(Source: Author compilation through HDFC Life Annual Reports)

HDFC Life: A Tale of overshooting banca, underwhelming agency \& a surging online presence

HDFC Life Insurance Company Limited (Formerly HDFC Standard Life Insurance Company Limited) is a joint venture between HDFC Ltd, a leading financial institution of India and Standard Life Aberdeen, a global investment company.

Established in 2000, HDFC Life prides itself in being a long-term life insurance solutions provider in India, offering a range of solutions that meet various customer needs like Protection, Pension, Savings, Investment and Health. As on March 31, 2019, the Company had in its resource-base, 38 individual and 11 group products, along with 8 optional rider benefits, catering to a diverse range of customer needs.

HDFC Life was never seen as a firm with a strong agent base. Rather, it has fortified the bancassurance space with tie-ups with varied banks and other partners. All through the strategy has been to leverage the captive base of these partners. As a result, HDFC Life continues to benefit from its presence across the country with 412 branches and additional distribution touchpoints through several partnerships. It has 265 bancassurance partners including NBFCs (Non-Banking Financial Companies), MFIs (Micro Finance Institutions), SFBs (Small Finance Banks), etc. and has 39 partnerships within non-traditional ecosystems. The Company also boasts of a strong base of financial consultants.

A point of note is that HDFC Life, in all its existence, have for some strange reasons put more emphasis on bancassurance, to the extent that barring last fiscal, it has overshooted the industry numbers (for private players). The agency numbers already dismal as compared to the industry - have continued to slide to or at best matched the numbers of the previous fiscals.

\section{RESULTS / FINDINGS}

The problem at HDFC LIfe: Changing paradigms of distribution

While one may argue that the lack of a strong agent base did hurt HDFC Life somewhere, the strong business numbers it has posted all along validates a heavy bancassurance reliant strategy. With life insurance primarily being 'an unsought product', the interaction element can never go away, which, therefore warrants a decent agency foothold. The problem, though doesn't end there. If the agency has been as awful as ever, the bancassurance numbers for the last few years have also been below the industry trend (sans LIC). The direct channel (mailnly online), though, has grown consistently, even by a whopping $12 \%$ in the last year and much is talked about its potential. But the fact should not be missed that its growth doesn't necessarily translate into big ticket size policies; rather small simple policies are sold more on volume. But probably an auto-correction - as and when it happens with the upcoming generation - would pave way for the online channel's consolidation when individuals would start buying all types of policies through it. So what would HDFC Life do in the interim (till the new generation starts buying all types of life insurance)? Dispense with the agency, ignore the banca? Or go gaga over technology making inroads and promoting online as a channel of choice when currently online is not preferred for costly and complex life insurance policies? How does it strike the balance? After all multi-distribution is the order of the day, yet it seems all lopsided and illogical for HDFC Life. We shall, in all earnest, seek some solutions. 
Exhibit 6: ICICI Prudential channel business numbers (premium)

\begin{tabular}{|l|l|l|l|}
\hline $\begin{array}{l}\text { ICICI } \\
\text { PRUDENTIAL }\end{array}$ & AGENT & BANK & $\begin{array}{l}\text { DIRECT } \\
\text { ONLINE }\end{array}$ \\
\hline $2014-15$ & $30.60 \%$ & $69 \%$ & $12 \%$ \\
\hline $2015-16$ & $30.20 \%$ & $70 \%$ & $14 \%$ \\
\hline $2016-17$ & $29.10 \%$ & $71 \%$ & $17 \%$ \\
\hline $2017-18$ & $32.70 \%$ & $67 \%$ & $21 \%$ \\
\hline $2018-19$ & $28.20 \%$ & $72 \%$ & $23 \%$ \\
\hline
\end{tabular}

(Source: Author compilation through ICICI Prudential Annual Reports)

Exhibit 7: ICICI Prudential channel business numbers (premium)

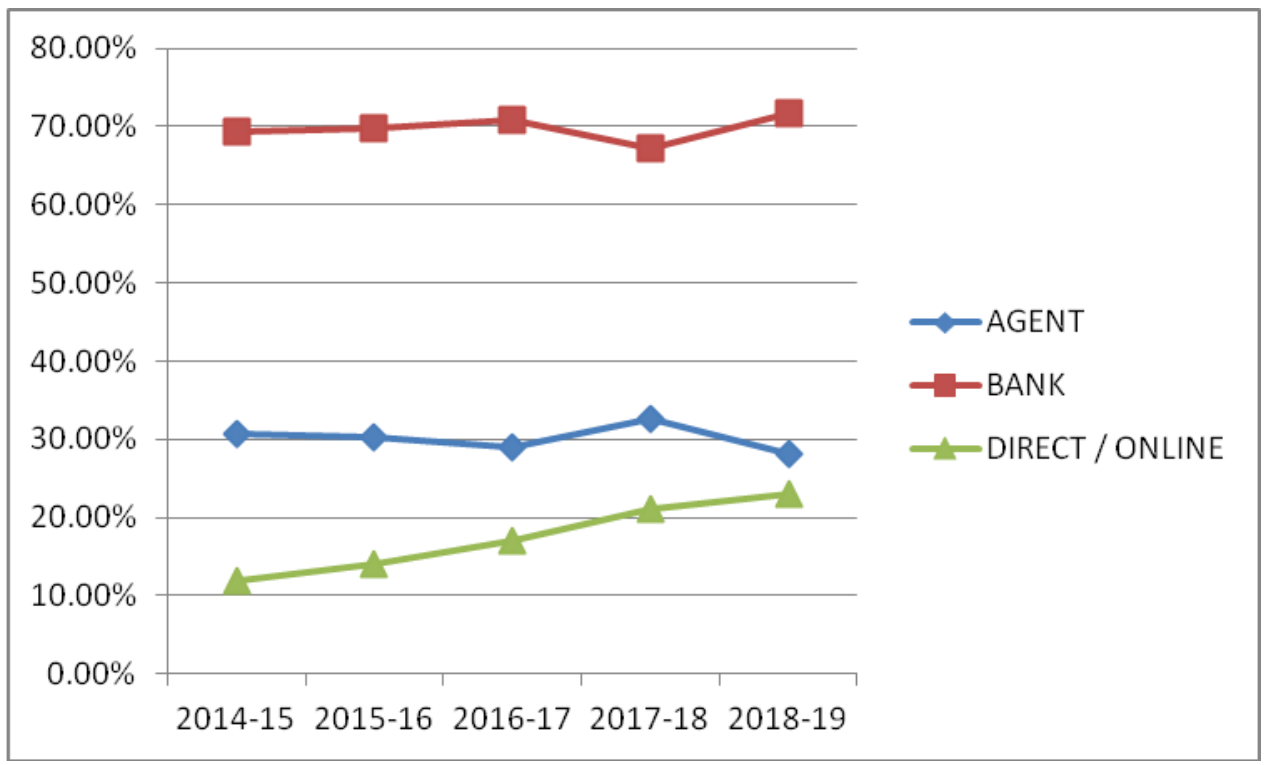

(Source: Author compilation through ICICI Prudential Annual Reports)

\section{ICICI Prudential: Overshooting banca numbers, preserving agency, scope for online}

ICICI Prudential Life Insurance Company Limited (ICICI Prudential Life), promoted by ICICI Bank Limited and Prudential Corporation Holdings Limited, began its operations in the year 2001 and has been a proven performer in the Indian life insurance sector. The Assets Under Management (AUM) as on 31 March 2019 stand at ₹1,604.10 billion. In a first, FY2015 saw ICICI Prudential become the first private life insurer to attain assets under management of $₹ 1$ trillion. Another first in India saw it to be listed on the NSE and the BSE.

ICICI Prudential, historically, has had good agency numbers - to the extent that in the financial year 2011-12, the agents generated more premium than banca - without losing hold on bancassurance, in fact even bettering the industry trend. With the company focusing on a multi-distribution mechanism trying to increase the outreach and intending to serve the customer at multiple touch-points, the distribution landscape is a vast departure from the heady days of the early part of the first decade of the new millennium when one or two channels held sway.

\section{RESULTS/ FINDINGS}

\section{The Problem at ICICI Prudential: Changing paradigms of distribution}

Unlike HDFC Life, ICICI Prudential has either preserved agency numbers or at times matched the industry over the years, even overtaking them on occasions. This coming from the stable of the ICICI group (ICICI Prudential is ICICI bank-promoted) is a welcome change as agents can never be dispensed with atleast for the foreseeable future as personal guidance coupled with hassle free claims make them a formidable force, still. Certain noted observations in this regard are: ICICI Prudential seems to have made a smart move by recognising the importance of agency. But while the agency numbers are excellent, will banking too much on the bancassurance numbers - ahead of the industry trend, by far for last many years - at a time when the direct channel (mainly online) is still finding its feet turn out to be a risky proposition? Or enhancing agency even more at the expense of the banca do the trick? Or positioning a niche in the direct channel (online) suffice? Distribution balancing woes seem to have stuck up ICICI Prudential. What is the way out? Or if indeed there is a way out because of the evolving nature of distribution, disrupted by 
technology? We, during the course of the paper, shall seek some solutions.

Probable solutions to the distribution problems at HDFC Life \& ICICI Prudential:

The answer - there could be differing points of view, though - we believe lie in a recent NIIT Technologies (2019) report as well as a report by Cognizant Technologies (2014). The former, while stressing the need for a multi-distribution network, suggests that companies choose the distribution mix according to defined customer segments (Exhibit 8). It identifies a host of channels, including the up and coming ones, and suggests suitable customer segments to be approached by each of the channels. The latter suggests that it is increasingly important to adopt a multi-distribution structure as customer buying, in the future, will invariably be influenced by their experiences across different industries. It further states that multi-distribution structure being the need of the hour, though, carries the risk of channel conflict. Towards that end, a unified view of the channel, the customer and the company is the way forward towards meeting the future of distribution (FOD). It further states that with the market becoming more diverse and new regulations taking place, traditional channels (mainly the agents) will have to innovate. Perhaps we shall, in due course see agency being persisted but in all altogether different avatar, tell-tale signs of which have already started to happen with the incorporation of technology into agency. Last but not the least, the report states that channels will (or rather have started) influence products and hence other than the 'channels for the segments' proposition put forth by the NIIT Technologies Report, choice of channel will dictate the type of insurance policy sought (Exhibit 9).

Exhibit 8: Balancing the distribution mechanism (Future Ready: Multi-Channel Distribution in Life Insurance; NIIT Technologies)

\section{Market Segment}

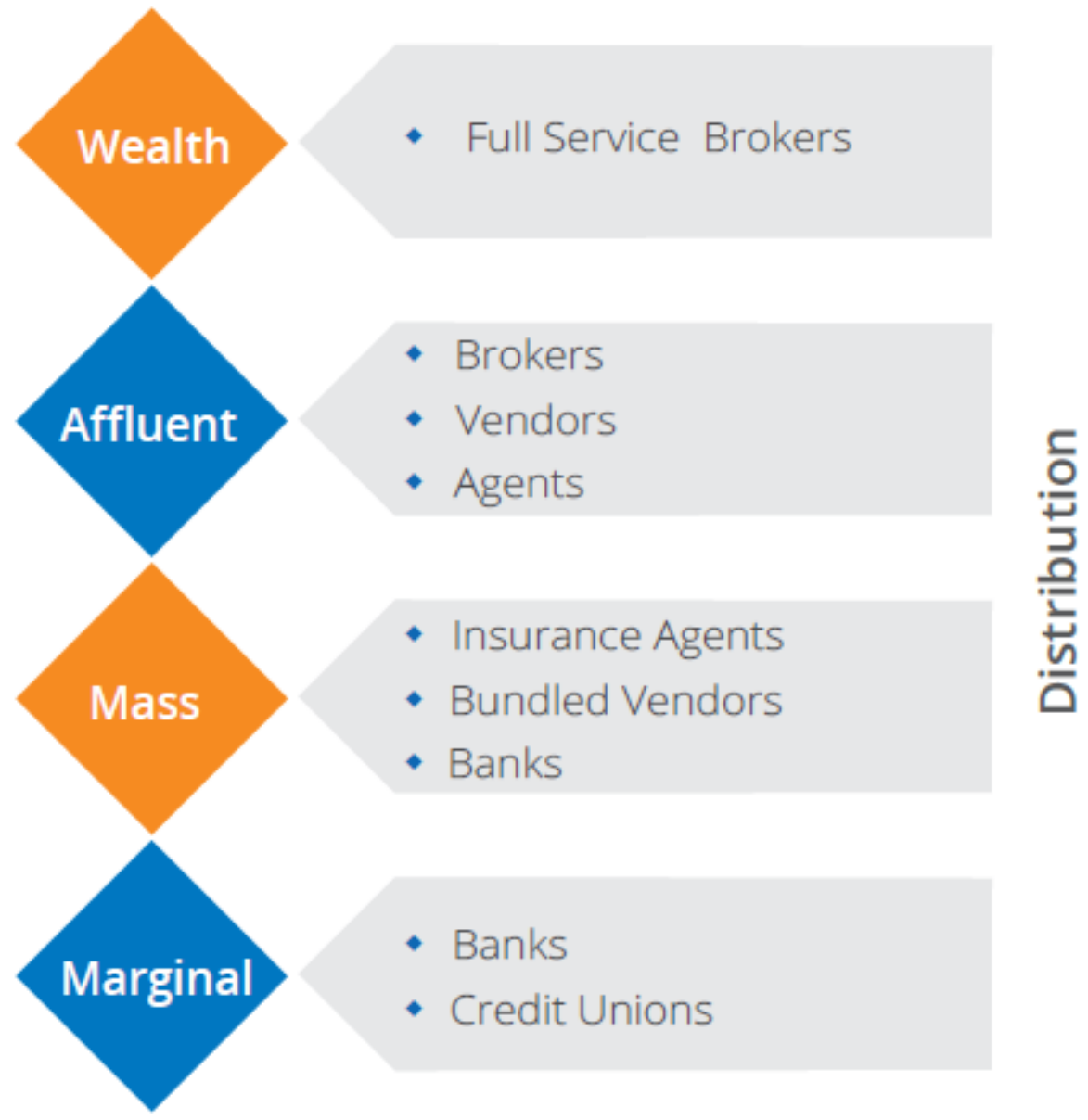

(Source: NIIT Technologies Report - Future Ready: Multi-Channel Distribution in Life Insurance) 
Exhibit 9: Balancing the distribution mechanism (Future of Distribution; Cognizant Technologies)

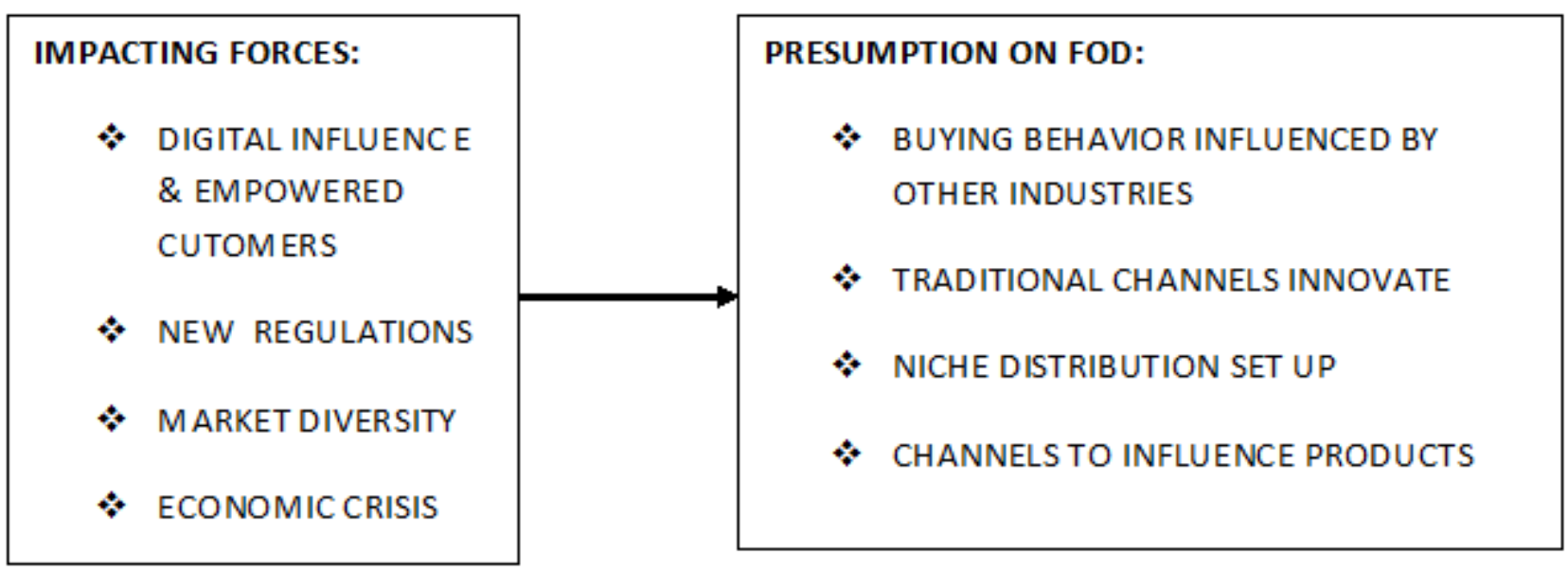

As mentioned above, the two solutions are and need not be the 'be all and end all' of the distribution puzzle faced at HDFC Life \& ICICI Prudential. Open to embracing a multi-distribution mechanism, HDFC Life in its Annual Report (2018-19) mentioned that it is working assiduously towards having multiple touch-points for the customer, thereby expanding its outreach. ICICI Prudential, too has voiced a similar stance. Balancing, though would remain a challenge. As far as the future of distribution is concerned, everything mentioned above is in the realm of possibility as is a totally new distribution landscape with further disruptions. Even an integrated financial system combining the best features of all the channels is not ruled out (although it is in existence even if not spread). Anticipation of the future of distribution and preparing accordingly should be the way out.

Our take is that while the two solutions (NIIT Technologies White Paper, 2019 \& Cognizant Report, 2014) offer suitable solutions for the immediate present, working out a workable distribution model in light of constraints is indeed a challenge but not impossible. With data analytics and the technology at hand, predicting a balanced distribution structure is possible and that is what the two companies in question are resorting to. That will go a long way in easing out the distribution woes these companies are currently faced with.

\section{CONCLUSION}

For two similar private bank led companies i.e. HDFC Life and ICICI Prudential, the distribution structure shows marked variations and the ubiquitous distribution problem - that of designing an optimum distribution mix - manifests itself differently for both of them. Agency, though currently lagging behind Bancassurance, can never be dispensed with fully. Similarly, not strengthening Banacassurance would mean not adapting with the times. And, lastly, the direct / online channel is a potential game-changer and channel of the future and thus, cannot be ignored. Finding the optimum balance in the distribution structure with the evolving nature of life insurance distribution is not an easy proposition. As HDFC Life and ICICI Prudential have witnessed changing paradigms in their distribution set-ups, it will only be apt to

say that though balancing the distribution mix is challenging, these companies should set forth their priorities of customers and subsequently cater to them with the appropriate channel mix. With further disruptions anticipated in the distribution space, multiple customer touch-points, although being a good strategy, is fraught with risks like channel conflicts, channel misalignment etc. The way these companies approach the changing landscape, will invariably, decide how they find a way towards an optimum distribution mix.

\section{REFERENCES}

1. Baranoff, E.G., Baranoff, D. and Sager, T.W. (2000) 'Nonuniform regulatory treatment of broker distribution systems. An impact analysis for life insurers', Journal of Insurance Regulation 19: 94-118.

2. Barrese, J., Nelson, J. M., 1992. Independent and Exclusive Agency Insurers: A Reexamination of the Cost Differential. Journal of Risk and Insurance 49, 375--397.

3. Baumol, W.J., Panzar, J.C. and Willig, R.D. (1982) Contestable Markets and the Theory of Industry Structure, New York: Harcourt College Pub.

4. Bearden, A. 2004 Marketing principles and perspective, Fifth edition. New York: McGraw Hill Companies Inc.

5. Benoist, G. (2002) 'Bancassurance: The new challenges', The Geneva Papers on Risk and Insurance 27 (3): 295-30

6. Bergendahl, G. (1995) 'The profitability of Bancassurance for European banks', International Journal of Bank Marketing 13 (1): 17-29.

7. Berger, A.N., Cummins, J.D. and Weiss, M.A. (1997) 'The coexistence of multiple distribution systems for financial services: The case of property-liability insurance', Journal of Business 70: 515-546.

8. Chang, Pang Ru, Peng, Jin-Lung, and Fan, Chiang Ku, The Geneva Papers on Risk and Insurance. Issues and Practice, Vol. 36, No. 1 (January 2011), pp. 76-93

9. Chen, T.Y. and Yeh, T.H. (1998), "Study of efficiency evaluation in Taiwan's banks",

10. International Journal of Service Industry Management, Vol. 9 No. 5, pp. 402-15.

11. Chen, Su Mei \& Chang, Long Pao. (2010). Distribution channel strategy and efficiency performance of the life insurance industry in Taiwan Journal of Financial Services Marketing. 15. 10.1057/fsm.2010.6.

12. Coelho, F.J., Easingwood, C., 2004. Multiple Channels in Services: Pro, Cons and Issues. The Service Industries Journal 24, 1.-29.

13. Crawford, Robert \& R. Klein, Benjamin \& A Alchian, Armen. (1978) Vertical Integration, Appropriable Rents, and the Competitive Contracting Process. Journal of Law and Economics. 21. 297-326. $10.1086 / 466922$ 
14. Cummins, J. D., VanDerhei, J., 1979. A note on the relative efficiency of property-liability insurance distribution systems. Bell Journal of Economics and Management Science 10, 708--719.

15. Dzienziol, J., Eberhardt, M., Renz, A., Schackmann, J., 2002. Multi-Channel Pricing for Financial Services, in: Sprague, R.H. (Ed.), Proceedings of the 35th Hawaii International Conference on System Sciences, Los Alamitos, Calif. et al.: IEEE Computer Society.

16. Easingwood, C., Coelho, F., 2003. Single versus Multiple Channel Strategies: Typologies and Drivers. The Service Industries Journal 23, 31--46.

17. Easingwood, C., Storey, C., 1996. The Value of Multi-Channel Distribution Systems in the Financial Services Sector. The Services Industries Journal 16, 223--241.

18. Field, L.P., Froser, D.R. and Kolarl, J.W. (2007), "Bidder returns in bancassurance mergers: is there evidence of synergy", Journal of Banking \& Finance, Vol. 31 No. 12, pp. 3646-62.

19. Finsinger, J., Schmidt, F.A., 1993. Gebundener versus ungebundener Vertrieb. Schmalenbachs Zeitschrift für betriebswirtschaftliche Forschung 45, 216--226.

20. HDFC(https://brandsite-static.hdfclife.com/media/documents/apps/An nual-Report\%20-\%20FY\%202018\%20\%E2\%80\%93\%202019.pdf

21. https://www.cognizant.com/InsightsWhitepapers/preparing-life-insurer s-for-the-future-of-distribution-codex1124.pdf

22. https://www.iciciprulife.com/content/dam/icicipru/aboutus/FinancialIn formation/AnnualReports/FY2018-AnnualReport.pdf

23. https://www.niit-tech.com/resource-library/white-papers/future-readymulti-channel-distribution-life-insurance

24. Joskow , P.) ( 1973 ) Cartels, competition and regulation in the property-liability insurance industry . Bell Journal of Economics and Management Science $4: 375-427$

25. Kotler, P. and Keller, K. (2006) Marketing Management. 12th Edition, Prentice Hall, Upper Saddle River. Marcel Corstjens and Peter Doyle, (1979), Channel Optimization in Complex Marketing Systems, Management Science, 25, (10), 1014-1025

26. Lakshmikutty, S. \& Bhaskar, S. (2005). Insurance distribution in India A perspective. Journal of Insurance Chronicle, 5(6), pp 17-22.

27. MehtaK.(2015)https://www.livemint.com/Money/vkrMCcZklJIiU69gl $\mathrm{MiNaL} / \mathrm{The}$-need-to-build-deeper-insurance-distribution-landscape.ht $\mathrm{ml}$

28. Morgan, G. (1994), "Problems of integration and differentiation in the management of 'Bancassurance'", The Service Industries Journal, Vol. 14 No. 2, pp. 53-169.

29. Regan, Laureen (1999). "Expense Ratios Across Insurance Distribution Systems: An Analysis by Line of Business." Risk Management and Insurance Review 2, (pages)

30. Regan, Laureen and Larry Tzeng (1999). "Vertical Integration and Ownership Form in the Property-Liability Insurance Industry." Journal of Risk and Insurance 66, 253-274.

31. Salomon, B. (1990), Multinational Money Center Banking: The Evolution of a Single European Banking Market, Salomon Bros, London.

32. Satsangi, R. (2014). An analysis of effectiveness of bancassurance as a distribution Channel in India. Delhi Business Review, 15(1), 41-52.

33. Scovotti, C. and Spiller, L.D. (2006), "Revisiting the conceptual definition of direct marketing: perspectives from practitioners and scholars", Marketing Management Journal, Vol. 16 No. 2, pp. 188-202.

34. Sinha, A. (2013). Emerging trends in distribution in the Life Insurance sector in India: A Study of a few Leading Players. Indian Journal of Marketing, 53-61

35. Sharma, R.P. \& Saxena, K. (2009). Life Insurance Marketing In India: Leveraging the strengths of Multi-Channel Distribution. Journal of Marketing trends, 8th Marketing trends congress, January 15-17, 2013

36. R. Thomas, Andrew. (2007). The end of mass marketing: Or, why all successful marketing is now direct marketing. Direct Marketing: An International Journal. 1. 6-16. 10.1108/17505930710734107.

37. Tang, F.-F., \& Xing, X. (2001). Will the Growth of MultiChannel Retailing Diminish the Pricing Efficiency of the Web? Journal of Retailing, 77, 319-333.

38. Tone, K. and Sahoo, B.K. (2005), "Evaluating cost efficiency and returns to scale in the Life Insurance Corporation of India using data envelopment analysis", Socio-Economic Planning Sciences, Vol. 39, pp. 261-85.

39. Tsay, A.A., Agrawal, N., 2004. Modeling Conflict and Coordination in Multi-Channel Distribution Systems, in: Simchi-Levi, D., Wu, D.S., Shen, Z.-J. (Eds.), Handbook of Quantitative Supply Chain Analysis, Springer, New York et al., pp. .557-606.

40. Webb. K.L., 2002. Managing channels of distribution in the age of electronic commerce. Industrial Marketing Management 31, 95--102.
41. Wilkinson, T., McAlister, A., Widmier, S. (2007), "Reaching the International Consumer, An Assessment of the International Direct Marketing Environment", Direct Marketing: An International Journal, Vol. 1, Nr. 1, pp. 17-37

42. Williamson, O. (1981). The economics of organization: The transaction cost approach. The American Journal of Sociology, 87(3), 548-577 